\title{
28. JURASSIC AMMONOIDEA FROM THE MAZAGAN SLOPE, MOROCCAN CONTINENTAL MARGIN, DEEP SEA DRILLING PROJECT LEG $79^{1}$
}

\author{
Otto Renz, Museum of Natural History, Basel ${ }^{2}$
}

\section{INTRODUCTION}

The objective of Leg 79 was to improve our understanding of the paleotectonic and sedimentary evolution of the continental margin off Morocco during rifting and separation of the African and American Plates. Samples containing Ammonoidea were obtained from Site 545, located at the foot of the $3000 \mathrm{~m}$ high Mazagan Escarpment as well as from Holes 544A and 547B, both situated west of the Escarpment on the Mazagan Slope. A belt of diapiric salt structures lies seaward, separating the margin from flat-lying sediments and oceanic crust to the west.

In contrast to most oceanic deposits in which ammonite shells are usually compressed and septa generally dissolved, the ammonite shells found along the Mazagan margin were not flattened by overburden. The ammonites are preserved as internal molds, and the sutures are well preserved.

\section{Site 545}

Site 545 (latitude $33^{\circ} 39.86^{\prime} \mathrm{N}$, longitude $09^{\circ} 21.88^{\prime} \mathrm{W}$ ) is situated in $3150 \mathrm{~m}$ water depth near the foot of the steep Mazagan Escarpment (sub-bottom depth, $701 \mathrm{~m}$ ). Jurassic sediments were first encountered between Core 545-56 and 545-57 at 530 m sub-bottom. The Jurassic sediments are unconformably overlain by Aptian nannofossil chalks. The deepest sediment drilled is limestone, Oxfordian in age; the age is suggested by the presence of Sowerbyceras obtained from Core 545-68.

Sample $545-68-3,14-16 \mathrm{~cm}$ is a pale yellow-brown limestone. Abundant dolomite rhombs occur in a pelmicritic matrix (Pl. 1, Fig. 10). Foraminifers are rare and skeletal components mostly consist of echinoderm and mollusk fragments. Some intraclasts are enveloped by micrite, possibly of algal origin; however, internal structures are not visible. Terrigenous material is reduced to very small quartz grains and occasional mica flakes.

\section{Family PHYLLOCERATIDAE Zittel, 1884 Genus SOWERBYCERAS Parona and Bonarelli, 1897 Subgenus SOWERBYCERAS Wiedmann, 1963 \\ Sowerbyceras (Sowerbyceras) sp. \\ (Pl. 1, Fig. 2a, b)}

The fragment represents the end of the phragmocone. One of the characteristic biconcave periodic constrictions is exposed. The tongue-

\footnotetext{
${ }^{1}$ Hinz, K., Winterer, E. L., et al., Init. Repts. DSDP, 79: Washington (U.S. Govt. Printing Office).

2 Address: Naturhistorisches Museum Basel, Augustinergasse 2, CH-4001 Basel, Switzerland.
}

like, very pronounced inflection on the ventrolateral shoulder is clearly recognizable. Adapically, the dorsal part of the previous constriction is preserved, indicating the distance between constrictions. The external suture line, as far as preserved, compares satisfactorily with that of Sowerbyceras (Sowerbyceras) protortisulcatum (Pompeckj) dredged by Vema from the Mazagan Escarpment (Renz et al., 1975, pl. 1, fig. 1d). The external lobe, which should be equally long as the lateral lobe, is unfortunately not exposed (Pl. 1., Fig. 2b).

\section{Hole 547B}

Hole 547B $\left(33^{\circ} 46.84^{\prime} \mathrm{N}, 09^{\circ} 20.98^{\prime} \mathrm{W}\right)$ is located on the southeastern down-faulted margin of a basement high west of the Mazagan Escarpment. The sub-bottom depth is $1030 \mathrm{~m}$; however, basement was not reached. Jurassic to Lower Cretaceous limestone is unconformably overlain by Albian nannofossil claystones.

\section{Punctaptychus punctatus (Voltz) (Pl. 1, Fig. 1)}

Sample 547B-6-3, 142-143 cm. A fragmental specimen of a right valve with its ventral end and lateral facet missing has been recovered from a dark brick-red, soft argillaceous limestone rich in Saccocoma and echinoderm debris. The fragment distinctly exposes specific features of Punctaptychus punctatus, a form known from the Upper Jurassic (Tithonian) sections of the Tethysian realm in Europe, where it is widely distributed. An excellently preserved specimen of P. punctatus has been recovered from the base of the continental rise in the western North Atlantic basin (Leg 11, 105-33-2, 89-91 cm; Renz, 1972, pl. 1, figs. 5a-c). Another fragmental specimen comes from the Cape Verde Basin (Leg 41, 367-34-4, 64-65 cm; Renz, 1977, pl. 1, fig. 16). Both specimens come from red marly limestones and can be correlated with the Rosso ad Aptici Formation in Italy. For Sample 547B6-3, 142-143 cm, the occurrence of calpionellids in Core 6, Section 4, suggests a late Tithonian age (site report, this volume).

\section{Lamellaptychus sparcilamellosus (Gümbel)}

(Pl. 1, Fig. 4)

Sample 547B-7-3, 69-71 cm. A left valve is present with missing dorsal and ventral parts. Thus, only a short interval shows the characteristic, well-developed, adsymphysal ridge against which the lamellae bend and lean towards the ventral termination of the valve. L. sparcilamellosus is widely mentioned as appearing in the Alpine-Mediterranean facies province. It also exists in the Kimmeridgian in Switzerland and southern Germany (Trauth, 1938, p. 165, pl. 11, figs. 23-27), as well as in the Carpathian (Gasiorowsky, 1962, horizon IV, table 1, p. 22). Juvenile specimens of L. sparcilamellosus were recovered from the Atlantic Cap Verde basin, during Leg 41 at Site 367. This form is present in Core $367-35$ (367-35-5, 38-39 cm; 367-35,CC) which also contains other Lamellaptychi indicating a late Oxfordian to Kimmeridgian age (Renz, 1977, p. 502, pl. 1, figs. 8, 9). The occurrence of Saccocoma, Protoglobigerina, and Stomiosphaera and the absence of calpionellids in Core 547B-2 suggest a late Oxfordian to early Tithonian age, (site report, this volume).

\section{Lytoceras sp.}

Sample 547B-10-2, 96-98 cm is a light gray limestone that occurs as a clast in a debris flow deposit (Unit VIB, site report, this volume). This shallow water limestone clast consists of loosely packed cry- 
ptalgal oncoids set in a micritic to fine grained pelletal matrix (PI. 1, Figs. 7, 9). Foraminifers, skeletal fragments of mollusks, and semirounded intraclasts are apparently coated by algae (Pl. 1, Figs. 7, 9). The obviously redeposited lithology closely resembles that of the oncoidal limestone with Hoicophylloceras from Hole 544A. The pellets, however, are smaller (compare thin sections on Pl. 1, Fig. 5 with Figs. $7,9)$. The sample encloses a small fragment of a Lytoceras test, similar to the one from the Blake-Bahama Basin (Site 391, Renz, 1978, pl. 1, fig. 21) associated with Lamellaptychus angulocostatus (Peters), suggesting a Barremian age at that location. A reliable age assignment for this fragment of the Lytoceras test is not possible, as Lytoceras with such fine riblets range from Liassic to Late Cretaceous.

\section{Hole 544A}

Hole $544 \mathrm{~A}\left(33^{\circ} 46.00^{\prime} \mathrm{N}, 09^{\circ} 24.26^{\prime} \mathrm{W}\right)$ was drilled on the basement high situated on the northwestern margin of the Mazagan Slope, near Hole 547B. It penetrated $184 \mathrm{~m}$ of sediment overlying gneissic basement (184-235 m sub-bottom). Sample 544A-13-1, 115-117 cm, yielded a fragment of an ammonite, which most resembles Sowerbyceras (Holcophylloceras), suggesting a Jurassic, probably Oxfordian, age. It was recovered from a limestone sequence that is followed unconformably by lower Miocene sediments. Below the Jurassic limestone, mudstones and muddy sandstones of unknown age were crossed which, in turn, cover metamorphic basement (gneiss). The sample available is a pale yellow-brown, partly light brick-red, peloidal-oncoidal limestone. Color lines are sharp. It consists of loosely packed, complexly coated grains of various shapes. Some are elongated ellipsoidal to spheroidal with concentrically laminated, probably cryptalgal, cyanobacterian coatings. These coatings also contain sessile foraminifera (Nubecularia). Some of the algal-foraminiferal coatings surround formerly aragonitic mollusk shells that were replaced by solution-cavity fill (Pl. 1, Fig. 8, lower left corner). The centers of the coated grains may also consist of foraminifers, ostracodes, and subrounded small micritic intraclasts (PI. 1, Figs. 5,6 ). The peloids are embedded in a lime mud matrix with small skeletal debris. Echinoderm fragments are surrounded by an euhedral syntaxial calcite replacement rim. Terrigenous components are fine-grained quartz and a few mica flakes.

L. Hottinger (Geological Institute, Basel) recognized the following foraminifer genera: Spirillina, Frondicularia, Lenticulina, Ammobaculites cf. coprolithiformis sequana Mohler, Robulus, and Dentalina. A lithologically comparable algal limestone, with ammonites of Oxfordian age, including Holcophylloceras, was dredged by Vema on the lower part of the Mazagan Escarpment (Renz et al., 1975 , p. 437 , fig. 4 ; p. 444 , fig. 5 ).

\section{Family PHYLLOCERATIDAE Zittel, 1884 Genus SOWERBYCERAS Parona and Bonarelli, 1897 Subgenus HOLCOPHYLLOCERAS Spath, 1927 Sowerbyceras (Holcophylloceras) sp. (Pl. 1, Fig. 3a, b)}

Sample 544A-13-1, 115-117 cm. Specimen diagonally split into two halves of which the left half is available. The shell is dissolved and filled by coarse sparry calcite cement and voids between septa are coated with calcite rhombohedra. The cross-section of the ammonite (Pl. 1, Fig. 3a) shows an oval whorl section and a narrow umbilicus. The external suture line (Pl. 1, Fig. 3b), relatively well-preserved, can satisfactorily be compared with the suture of a Sowerbyceras (Holcophylloceras) dredged on the steep slope of the Mazagan Escarpment (Renz et al., 1975, pl. 1, fig. 4d). It clearly exhibits the external lobe which is characteristically short compared with the longer lateral lobe. Based on the suture line of the ammonite and the microfossils present in the formation (site report, this volume), the interval is most likely of Oxfordian age.

\section{ACKNOWLEDGMENTS}

The fossils studied were provided by P. O. Baumgartner. The specimens were photographed by W. Suter (Museum of Natural History, Basel). I am grateful to L. Hottinger (Geological Institute, Basel) for the determination of the foraminifera in the thin sections. The contribution has been reviewed by D. Bernoulli (Geological Institute, Basel).

\section{REFERENCES}

Gasiorowski, S. M., 1962. Aptychi from the Dogger, Malm and Neocomian in the Western Carpathians and their stratigraphical value. Stud. Geol. Polonica, 10:1-144.

Gümbel, C. W., 1861. Geognostische Beschreibung des bayerischen Alpengebirges und seines Vorlandes. Geogn. Beschr. K. Bayern, 1 (Gotha).

Mohler, W., 1938. Mikropaläontologische Untersuchungen in der Juraformation. Abh. schweiz. paläont. Ges., 60:1-53.

Parona, C. F., and Bonarelli, G., 1897. Fossili albiani d'Escragnolles, del Nizzardo e della Liguria occidentale. Palaeontographia Ital., 2: 53-112.

Peters, K., 1854. Die Aptychen der österreichischen Neocomien und oberen Juraschichten. Jb. K.K. Geol. Reichsanst., 5:439.

Pompeckj, J. F., 1863. Beiträge zu einer Revision der Ammoniten des schwäbischen Jura. Jh. Ver. Vaterl. Natkd. Württemb., 49: 151-248.

Renz, O., 1972. Aptychi (Ammonoidea) from the Upper Jurassic and Lower Cretaceous of the western North Atlantic (Site 105, Leg XI, DSDP). In Hollister, C. D., Ewing, J. I., et al., Init. Repts. DSDP, 11: Washington (U.S. Govt. Printing Office), 607-629.

1977. Aptychi (Ammonoidea) from the Late Jurassic and Early Cretaceous of the eastern Atlantic DSDP Site 367. In Lancelot, Y., Seibold, E., et al., Init. Repts. DSDP, 41: Washington (U.S. Govt. Printing Office), 499-513.

1978. Aptychi (Ammonoidea) from the Early Cretaceous of the Blake-Bahama Basin. Leg 44, Hole 391C, DSDP. In Benson, W. E., Sheridan, R. E., et al., Init. Repts. DSDP, 44: Washington (U.S. Govt. Printing Office), 899-909.

Renz, O., Imlay, R., Lancelot, Y., and Ryan, W. B. F., 1975. Ammonite-rich Oxfordian limestones from the base of the continental slope of northwest Africa. Eclogae Geol. Helv., 68(2):431-448.

Trauth, R., 1938. Die Lamellaptychi des Oberjura und der Unterkreide. Palaeontographica A, 88:115-229.

Voltz, P. L., 1837. Zweiter Vortrag über das Genus Aptychus. N. Jb. Mineral. Geol. Paläont., p. 432.

Wiedmann, J., 1963. Unterkreide-Ammoniten von Mallorca. 2. Liefg.: Phylloceratina. Abh. Akad. Wiss. Lit. Mainz, Math. Natw. Kl. 4: 161-264.

Zittel, K. A., 1884. Handbuch der Palaeontologie. Bd. 2, Cephalopoda, pp. 329-522.

Date of Initial Receipt: December 10, 1982

Date of Acceptance: July 15, 1983 

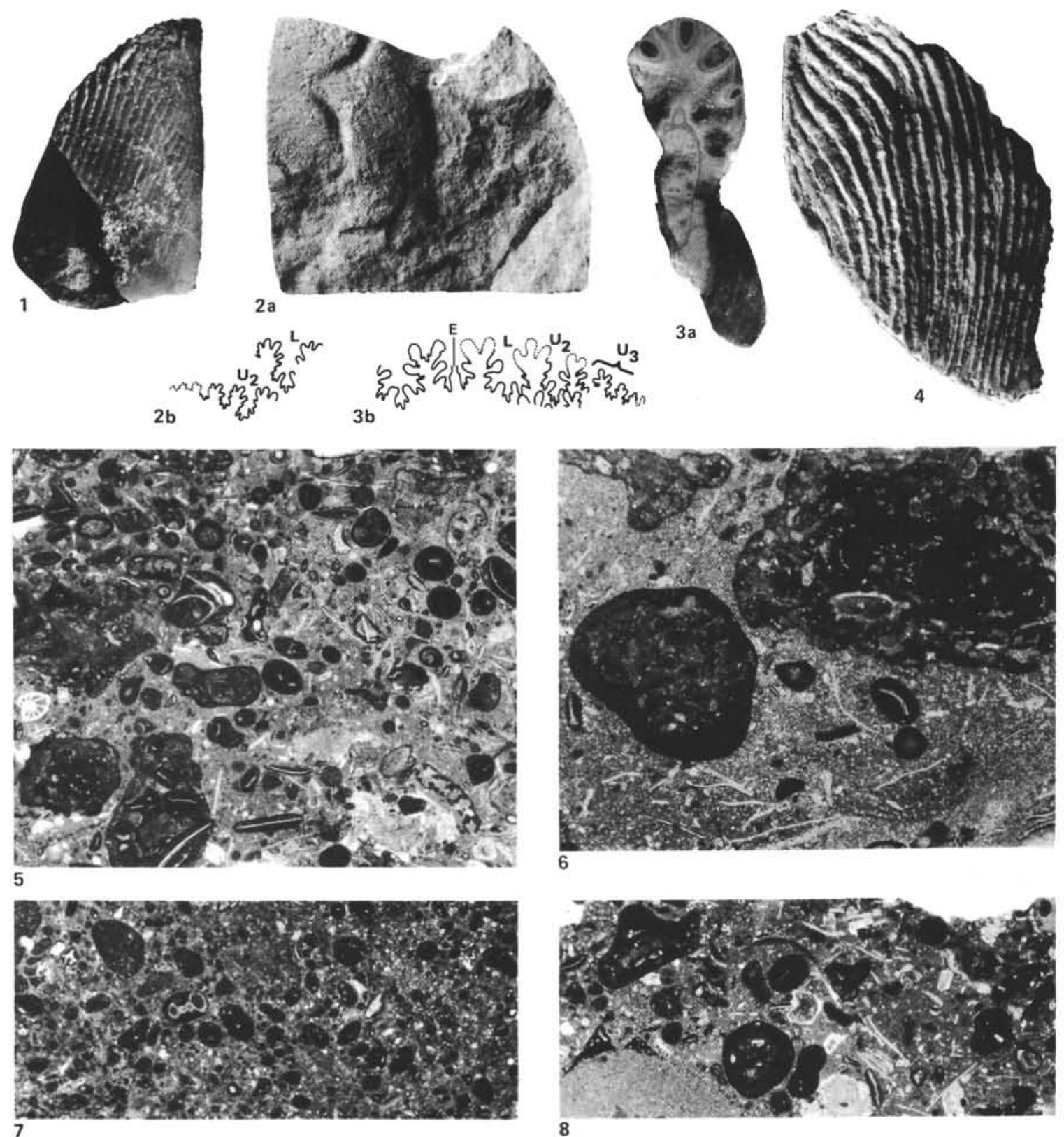

6
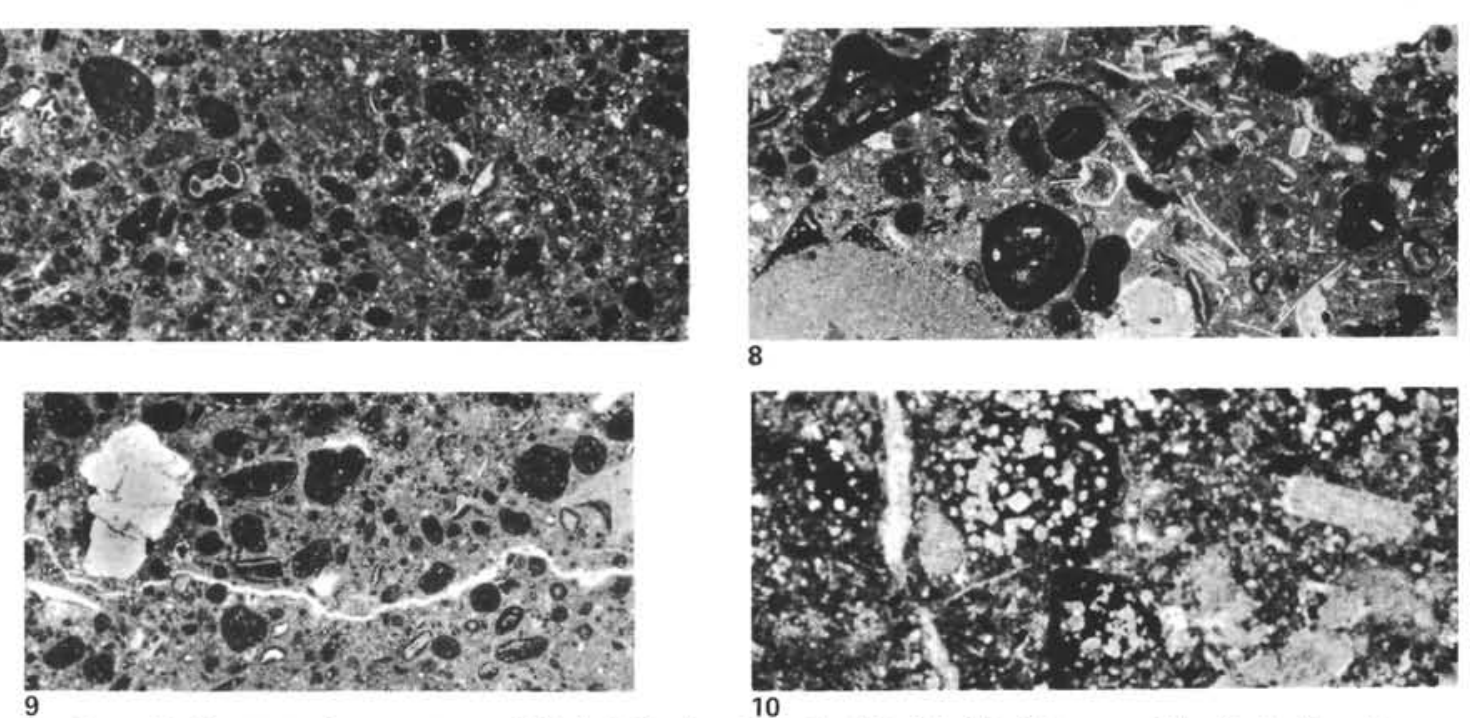

Plate 1. Ammonoidea. 1. Punctaptychus punctactus (Voltz), Tithonian, Sample 547B-6-3, 142-143 cm, $\times 1.7$. 2a-b. Sowerbyceras (Sowerbyceras) sp., Oxfordian, Sample 545-68-3, 14-16 cm, (2a) Phragmocone with constrictions, $\times 1.7$, (2b) External suture line, $\times 3.4$. 3a-b. Sowerbyceras (Holcophylloceras) sp., Oxfordian, Sample 544A-13-1, 115-117 cm, (3a) Cross-section with fragment of body chamber, $\times 1.7$, (3b) External suture line, $\times 3.4 .4$. Lamellaptychus sparcilamellosus (Gümbel), late Oxfordian to early Tithonian, Sample 547B-7-3, 69-71 cm, $\times 1.7$. 5. Oncoidal limestone with Lenticulina (left edge) and lituolid foraminifers (lower right), Sample 544A-13-1, 115-117 cm, thin section, $\times 8.6$. 6. Large oncoids consisting of intraclasts, encrusted by laminated algal material, Sample $544 \mathrm{~A}-13-1,115-117 \mathrm{~cm}$, thin section, $\times 17.2$. 7. White oncoidal limestone with remains of a mollusk and brittle star vertebrae (left side), coated by cryptoalgal material, Sample 547B-10-2, $96-98 \mathrm{~cm}$, thin section, $\times 8.6$. 8. Oncoidal limestone with sessile foraminifers on left side (Nubecularia), Sample $544 \mathrm{~A}-13-1,115-117 \mathrm{~cm}$, thin section, $\times 8.6$. 9. Oncoidal limestone with a lithoclast derived from the basement, Sample 547B-10-2, 96-98 cm, thin section, $\times 8.6$. 10. Dolomitic limestone with echinoderm fragments, dark micritic margins might indicate algal oncoids, Sample 545-68-3, 14-16 cm, thin section, $\times 8.6$. 